\title{
Reduced Intracellular T-Helper 1 Interferon-Gamma in Blood of Newly Diagnosed Children With Crohn's Disease and Age-Related Changes in Th1/Th2 Cytokine Profiles
}

\author{
NINA HOLLAND, JING DONG, ELIZABETH GARNETT, NISHAT SHAIKH, KAREN HUEN, PAUL HARMATZ, \\ ANTHONY OLIVE, HARLAND S. WINTER, BENJAMIN D. GOLD, STANLEY A. COHEN, ROBERT N. BALDASSANO, \\ BARBARA S. KIRSCHNER, AND MELVIN B. HEYMAN
}

\begin{abstract}
School of Public Health [N.H., J.D., N.S., K.H.] and Department of Pediatrics [E.G., M.B.H.], University of California, San Francisco, California 94143; Children's Hospital \& Research Center Oakland [P.H.], California 94609; Texas Children's Hospital Clinical Care Center [A.O.], Baylor College of Medicine, Houston, Texas 77030; MassGeneral Hospital for Children [H.S.W.], Boston, Massachusetts 02114; Children's Healthcare of Atlanta [B.D.G., S.A.C.], Emory University, Atlanta, Georgia 30322; Children's Hospital of Philadelphia [R.N.B.], Philadelphia, Pennsylvania; University of Chicago [B.S.K.], Chicago, Illinois 60637
\end{abstract}

\begin{abstract}
Abnormal cytokine production by T-helper 1 (Th1)/ T-helper 2 (Th2) lymphocytes has been implicated in the pathogenesis of inflammatory bowel disease (IBD). Few studies have examined Th1/Th2 cytokine status in pediatric IBD patients, and results have been inconsistent. We used flow cytometric detection of intracellular IFN- $\gamma /$ IL- 4 cytokine production to investigate $\mathrm{CD} 4^{+}$, Th1, and Th2 cells in the peripheral blood of children with untreated, newly diagnosed Crohn's disease (CD) $(n=23)$ and matched healthy controls $(n=49)$. Th1 cytokine levels were lower in CD patients compared with controls $(p=0.006)$ and strongly correlated with levels of albumin and hematocrit $(r=0.51, p=0.007$ and $r=0.35$, $p=0.052$, respectively). An age-dependent increase in Th1 cells was observed ( $p<0.0005$ ); however, no correlation was found between age, clinical end points, $\% \mathrm{CD}^{+}{ }^{+}$, or Th2 cell numbers. In conclusion, the Th1 cytokine levels in blood are lower in early onset CD patients than in healthy children and are directly associated with diseaserelated clinical parameters. In future studies of pediatric IBD patients, it will be critical to consider the effect of age and disease progression on cytokine status in intestinal mucosa and peripheral blood. (Pediatr Res 63: 257-262, 2008)
\end{abstract}

$I^{n}$ nflammatory bowel disease (IBD) combines several chronic disorders of the gastrointestinal tract including Crohn's disease (CD), ulcerative colitis (UC), and indeterminate colitis (IC). In recent years, IBD prevalence has been increasing among children and adolescents, with more than $10 \%$ of patients diagnosed before 18 y of age, and 30\% diagnosed before their 21st birthday (1). The etiology of IBD is still largely unknown. Both genetic and environmental factors are likely involved $(2,3)$. The role of cytokines in the gastrointestinal mucosal immune system has been studied extensively (4-8). Cytokines determine the nature of the immune re-

Received August 1, 2007; accepted November 3, 2007.

Correspondence: Nina T. Holland, Ph.D., 733 University Hall, University of California, Berkeley, Berkeley, CA 94720-7360; e-mail: ninah@berkeley.edu

Supported by grants from the Crohn's and Colitis Foundation of America, and NIH (R03 DK063187, M01 RR01271 and K24 DK60617). The Pediatric IBD Consortium is supported by grants from the NIH and from private donor funds including Kacyra Foundation and Lucille Packard Foundation.

This paper's contents are solely the responsibility of the authors and do not necessarily represent official views of the private foundations, the Crohn's and Colitis Foundation of America, and NIH. sponse in IBD by rapidly synthesizing and secreting inflammatory mediators such as reactive oxygen metabolites, nitric oxide, platelet-activating factor, and prostaglandins (9-11).

$\mathrm{T}$ helper cells are a subgroup of lymphocytes that activate and direct other immune cells through release of cytokines. T helper 1 (Th1) cells are characterized by the production of IFN- $\gamma$, IL- 2 , and TNF- $\beta$. In contrast, T helper 2 (Th2) cells synthesize IL-4, IL-5, IL-9, and IL-13 (12). Both genetic factors and environmental stimuli influence the direction of differentiation of Th1 and Th2 subsets from naïve $\mathrm{CD} 4^{+} \mathrm{T}$ lymphocytes during development and maturation of the immune system (13). Naïve $\mathrm{CD} 4^{+}$cells develop into Th1 cells in response to microbial activation of antigen-presenting cells (APC) under the influence of IL-12. Differentiated Th1 cells secrete IFN- $\gamma$ to fight viruses and other intracellular pathogens, eliminate cancer cells, and stimulate delayed-type hypersensitivity (DTH) skin reactions (14). Th2 differentiation occurs in response to environmental allergens through APC under the influence of IL-4. Activated Th2 cells produce IL-4, IL-13, and IL-15 and therefore induce IgE production by B cells, eosinophil activation, and recruitment (15). Furthermore, Th1 and Th2 cells can cross-regulate each other (16).

An imbalance between Th1 and Th2 cytokines has been implicated in the pathogenesis of IBD (17) though data remains controversial. Earlier studies described increased levels of IFN- $\gamma$ mRNA detected by Northern blot analysis in intestinal mucosal lesions of IBD patients compared with controls $(7,8,18-20)$. Higher levels of IFN- $\gamma$ protein production have also been observed in intestinal mucosa of CD patients by enzyme-linked immunosorbent spot (ELISPOT) analysis (21), whereas lower amounts of IL- 4 mRNA and secreted protein are reported to be expressed in colonic lamina propria lymphocytes (LPLs) of IBD patients than in controls (22). Lower frequencies of IFN- $\gamma$ and IL-2 producing Th1 cells assessed by flow cytometry after PMI-ionomycin stimulation were found in colonic LPLs of adult patients with $\mathrm{CD}$ and UC

Abbreviations: CD, Crohn's disease; IBD, inflammatory bowel disease; Th1/Th2, T helper 1/T helper2 
compared with controls (15). A Th1-type pattern was also observed in the chronic ileal lesions by competitive reversetranscriptase PCR (17). However, the early ileal lesions of patients with $\mathrm{CD}$ were associated with a significant increase of IL-4 mRNA and a decrease of IFN- $\gamma$ mRNA (compared with the normal mucosa of patients with $\mathrm{CD}$ or controls). This finding suggests divergent cytokine patterns during different clinical stages of CD (17).

Most studies focus on adult patients with long-standing disease undergoing medical treatments that may influence cytokine profiles. In a previous study of 18 treated children (2-16 y) with active CD, IFN- $\gamma$ secreting cells were readily detectable in intestinal mucosa from the patients with $\mathrm{CD}$ compared with controls (8). Decreased numbers of IL-4 secreting cells were also detected by enzyme-linked-immunosorbent serologic assay (ELISA) in another study of 15 treated children with CD (23). Only one prior study was conducted on newly diagnosed children without treatment. The median percent of peripheral Th1 cells estimated by flow cytometric assay for normal subjects was similar to that of UC subjects, but greater than that of CD subjects (19).

Although Th1/Th2 cytokine balance has been routinely investigated in the pathogenesis of immunologic diseases, pediatric reference levels of Th1/Th2 are not well established (13). Adjustment for age is particularly important, since IFN- $\gamma$ expression and percentage of IFN- $\gamma$ producing Th1 cells increase with age in healthy infants and young children (2429), as a result of exposure to environmental immunogens that lead to generation of memory lymphocytes (27). Age-related changes in intracellular Th1/Th2 status in untreated IBD patients have not been previously addressed.

We compared intracellular Th1/Th2 cytokine profiles and investigated their ontogenetic dynamics in treatment-naïve pediatric $\mathrm{CD}$ patients and healthy control subjects.

\section{MATERIALS AND METHODS}

Study design. The present study is a prospective, case-control study conducted at seven major IBD programs and pediatric centers in San Francisco and Oakland, CA; Houston, TX; Atlanta, GA; Philadelphia, PA; Boston, MA; and Chicago, IL, in collaboration with the Holland laboratory at the University of California, Berkeley (UCB) where sample processing and analyses were performed. Patients and their parents/legal guardians provided written informed consent as approved by each of the local Institutional Review Boards.

Study subjects. Twenty-three CD patients and 49 healthy controls concurrently enrolled in an ongoing Pediatric Consortium study (30) provided blood samples that were analyzed for intracellular Th1/Th2 cytokines by flow cytometry. Inclusion criteria required that all subjects were not taking any antiinflammatory or other IBD-related medications (e.g., 5-ASAs, immunomodulators, biologic agents, or corticosteroids) at the time of enrollment and that control subjects had no preexisting acute or chronic illness. All recruited CD patients were newly diagnosed based on endoscopic, radiographic, and/or histopathologic criteria (30) and were untreated. Control subjects were frequency matched for age, gender, and race/ethnicity. Weight using digital scale and height by stadiometer were routinely measured and used to determine the body mass index [BMI; weight $(\mathrm{kg})$ divided by height $\left.{ }^{2}\left(\mathrm{~m}^{2}\right)\right]$. Subjects were categorized into three groups: underweight (BMI $\leq 18.5)$, normal weight $(18.5<\mathrm{BMI}<25)$, and overweight $(\mathrm{BMI}>25)$. Clinical analyses performed according to standard laboratory procedures in each participating clinical center included albumin concentration, hematocrit, and erythrocyte sedimentation rate (ESR), part of the pediatric Crohn's disease activity index that is used as a measure of disease severity (31).

Cell collection, activation, and culture. The procedure for collection and processing of pediatric samples for cytokine analysis by flow cytometry was previously described (28). Briefly, blood was collected in heparin-vacutainers by participating clinicians and shipped overnight to the University of California, Berkeley, where cytokine analysis was performed. Upon receipt, whole blood $(500 \mu \mathrm{L})$ was diluted $1: 1$ with RPMI 1640 in $12 \times 75 \mathrm{~mm}$ fluorescence-activated cell sorting tubes and activated with phorbol 12 myristate 13-acetate (PMA; 2.5 ng/mL, Sigma Chemical Co., St. Louis, MO) and ionomycin ( $1 \mu \mathrm{g} / \mathrm{mL}$, Sigma Chemical Co.). The cultures were incubated for $4 \mathrm{~h}$ at $37^{\circ} \mathrm{C}$ and $5 \% \mathrm{CO}_{2}$ in the presence of brefeldin $\mathrm{A}(10 \mu \mathrm{g} / \mathrm{mL}$, Sigma Chemical Co.), a transport inhibitor that prevents cytokine release from cells. Samples incubated with brefeldin A alone served as nonstimulated controls.

Fluorescent labeling and flow cytometry. Flow cytometric detection of intracellular Th1 and Th2 cytokines in small samples of whole blood from children has been carefully validated for use as a biomarker in epidemiologic studies (28). Whole blood $(200 \mu \mathrm{L})$ was pipetted directly into a $12 \times 75 \mathrm{~mm}$ fluorescence-activated cell sorting tube containing $20 \mu \mathrm{L}$ of MAb for the T-helper surface antigen $\mathrm{CD}^{+}{ }^{+}$(CD4-PerCP, Becton Dickinson, San Diego, CA) and incubated at room temperature in the dark for $10 \mathrm{~min}$. Then, $1 \%$ paraformaldehyde $(0.5 \mathrm{~mL})$ was added for $8 \mathrm{~min}$ to stabilize the MAb-surface antigen complex. RBCs were lysed using $3 \mathrm{~mL}$ of $1 \times$ fluorescence-activated cell sorting lysing solution (Becton Dickinson) for $8 \mathrm{~min}$. After centrifugation at $1930 \mathrm{rpm}$ for $5 \mathrm{~min}$, the supernatant was aspirated and $1 \times$ permeabilizing solution (500 $\mu \mathrm{L}$, Becton Dickinson) was added to the pellet and incubated for $10 \mathrm{~min}$ at room temperature in the dark. After washing with $3 \mathrm{~mL}$ buffer $\left(1 \%\right.$ BSA, $\left.0.1 \% \mathrm{NaN}_{3}, 1 \times \mathrm{PBS}\right)$, cytokine-specific antibodies $(20 \mu \mathrm{L}$, IFN- $\gamma$-FITC, IL-4-PE, Becton Dickinson) were added to the cells and incubated for $30 \mathrm{~min}$ at room temperature in the dark. After one final wash, cells were resuspended in $1 \%$ paraformaldehyde $(500 \mu \mathrm{L})$ and stored at $4{ }^{\circ} \mathrm{C}$ until flow cytometry analyses. Cells were acquired using a Beckman-Coulter EPICS XL flow cytometer (Miami, FL), and data were analyzed using CellQuest software. Percentages of Th1 and Th2 cytokine-producing cells were identified as the number of IFN- $\gamma$-positive and IL-4-positive cells present, respectively, in the total population of $\mathrm{CD}^{+}{ }^{+} \mathrm{T}$-helper cells (Fig. 1). A minimum of $5000 \mathrm{CD}^{+}$cells was counted from each sample. Fluorochrome-equivalent IgG2 isotype controls (Becton Dickinson) were used to detect nonspecific binding. Compensation for dual-fluorochrome spectral overlap was made using cells individually stained with FITC-only and PE-only antibodies.

The two criteria for inclusion of data points were: (1) the lymphocyte population must be clearly depicted in the scatter plot, (2) the density plot must have a clear separation between the negative and positive CD4 ${ }^{+}$ population (28).

Statistical analysis. The distributions of $\mathrm{CD}^{+}{ }^{+}, \mathrm{Th} 1$, and $\mathrm{Th} 2$ for three study populations were examined graphically and with summary statistics. Because Th1 and Th2 had right-skewed distributions, they were logtransformed for all analyses. CD4 values were normally distributed and were not transformed. We compared the levels of $\mathrm{CD}^{+}{ }^{+}$, Th1, and Th2 among CD patients and controls with two-tailed $t$ test. ANOVA analysis with post hoc tests using Bonferroni adjustment was used to compare the distribution of $\mathrm{CD} 4{ }^{+} \%$, Th $1 \%$, and $\mathrm{Th} 2 \%$ by gender, weight, BMI, and race. ANOVA was also performed to examine monthly difference of $\mathrm{CD}^{+}{ }^{+}$, Th1, and Th2 levels among $\mathrm{CD}$ patients and controls. Correlation analysis was performed to evaluate the relationship between clinical parameters and age, Th1\% (logtransformed), Th2\% (log-transformed) and $\mathrm{CD} 4 \%$. Additionally, we used multiple linear regression analysis to evaluate associations between age and cytokine levels $\left(\mathrm{CD} 4^{+}\right.$, log-transformed Th1, and log-transformed Th2) while adjusting for patient status (CD patients versus healthy controls). Statistical analyses were performed using Stata 9.2 for Windows.

\section{RESULTS}

Table 1 describes the sociodemographic characteristics of the CD patients and controls who had Th1/Th2 cytokine analysis performed. Among the 72 subjects, 57\% were males, over $80 \%$ were Caucasian, and $14 \%$ were Hispanic. The mean age of CD patients $(12.4 \pm 2.4 \mathrm{y})$ was similar to controls $(12.3 \pm 3.6 \mathrm{y})$. About $33 \%$ of the controls were overweight, whereas only $12 \%$ of the IBD patients had BMI greater than 25 , consistent with the finding that $\mathrm{CD}$ is associated with loss of appetite and weight (32). $\chi^{2}$ analysis showed that CD patients and controls did not differ in any of their demographic measures (Table 1).

Clinical parameters. CD patients had significantly lower levels of serum albumin $(3.5 \pm 0.5 \mathrm{~g} / \mathrm{dL}$ versus $4.2 \pm 0.9$ 

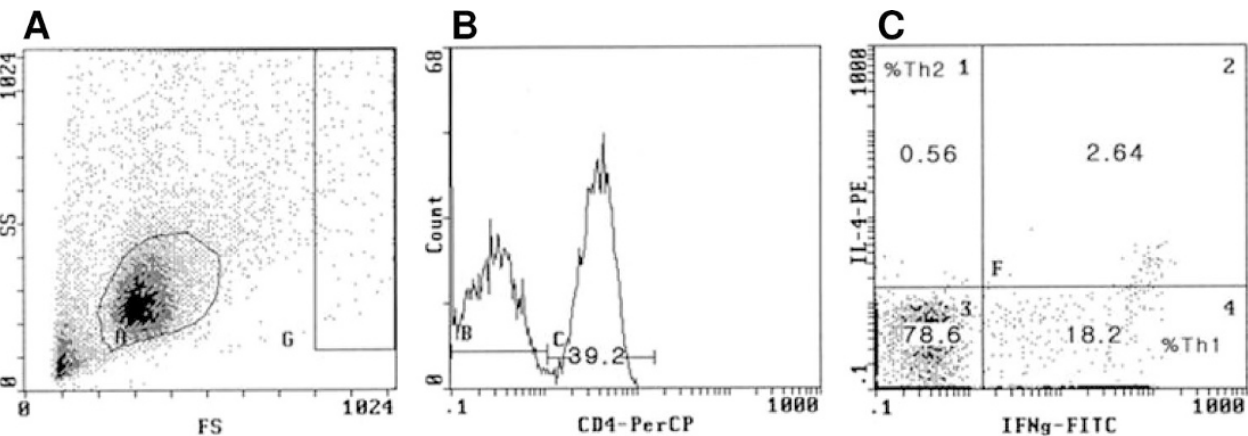

Figure 1. Flow cytometric detection of intracellular IFN- $\gamma$ production by T-helper cells. Whole blood stimulated with PMA/ionomycin was stained with cytokine-specific antibodies (IFN- $\gamma$-FITC for T-helper-1 cells and IL-4-PE for T-helper-2 cells). (A) In this scatter plot of all cells, a circular gate was placed around the live lymphocyte population, based on size (FS, forward scatter) and granularity (SS, side scatter). Of total lymphocytes, only the CD4 ${ }^{+} \mathrm{T}-$ helper cells were selected (right peak, $B$ ). These T-helper cells were examined for Th1/Th2 cytokine production $(C)$, with cells that stained positive for IFN- $\gamma$ only (lower right quadrant) classified as Th1 cells and those that stained positive for IL-4 only (upper left quadrant) classified as Th2 cells.

Table 1. Characteristics of study population by gender, race, ethnicity, age, and BMI

\begin{tabular}{lcccc}
\hline Characteristics & Total & Control $N(\%)$ & Patient $N(\%)$ & $p$ value \\
\hline Gender & & & & 0.65 \\
$\quad$ Male & 41 & $27(55.1)$ & $14(60.9)$ & \\
$\quad$ Female & 31 & $22(44.9)$ & $9(39.1)$ & \\
Race & & & & 0.60 \\
$\quad$ Black/AA & 7 & $4(8.2)$ & $3(13.0)$ & \\
$\quad$ White & 59 & $40(81.6)$ & $19(82.7)$ & \\
$\quad$ Others* & 6 & $5(10.2)$ & $1(4.3)$ & \\
Ethnicity & & & & 0.38 \\
Hispanic & 10 & $8(16.3)$ & $2(8.7)$ & \\
Non-Hispanic & 62 & $41(83.7)$ & $21(91.3)$ & \\
Age & & & & 0.10 \\
6-10 & 22 & $16(32.7)$ & $6(26.1)$ & \\
10-15 & 35 & $20(40.8)$ & $15(65.2)$ & \\
15-17 & 15 & $13(26.5)$ & $2(8.7)$ & \\
BMI & & & & 0.13 \\
12-18.5 & 26 & $14(28.6)$ & $12(52.2)$ & \\
18.5-25 & 26 & $19(38.8)$ & $7(30.4)$ & \\
$25-42.3$ & 26 & $16(32.6)$ & $4(17.4)$ & \\
\hline
\end{tabular}

* Others includes 1 2 individuals who self-identified as Asian, Native American, White and Native American Mixed race, White and Pacific Island Mixed race, or refused to define their race.

$\mathrm{g} / \mathrm{dL}, p=0.016)$ and hematocrit $(34.5 \pm 3.4 \%$ versus $39.6 \pm$ $3.7 \%, p=0.0007)$ compared with controls (Table 2). However, ESR levels did not differ between the two groups, possibly due to the large inter-individual variability of this measure $(29.7 \pm$ $25.4 \mathrm{~mm} / \mathrm{h}$ in CD patients compared with $23.7 \pm 15.3 \mathrm{~mm} / \mathrm{h}$ in controls, $p=0.56$ ). None of these three clinical markers differed significantly by gender, BMI, race, ethnicity (Table 3), or age (Table 4). The percentage of Th1 cells was significantly correlated with the levels of albumin $(r=0.509, p=0.007)$ and hematocrit $(r=0.352, p=0.052)$ (Table 4), but not with ESR. However, in patients with higher ESR levels, a negative association with percentage of Th1 cells approached significance $(p=0.07)$. Neither percentage of Th2 cells nor CD4 ${ }^{+}$ cells were associated with either of three clinical parameters (Table 4).

Frequency of $\mathrm{CD}^{+}$, Th1, and Th2 cells in CD patients and controls. Distributions of $\mathrm{CD} 4^{+}$, Th1, and Th2 cells for $\mathrm{CD}$ patients and controls are presented in Figure 2. CD patients had lower numbers of Th1 cells $(8.4 \%$; $95 \%$ CI,
Table 2. Comparison of albumin, hematocrit, and ESR levels in $C D$ patients and controls

\begin{tabular}{cccc}
\hline & $\begin{array}{c}\text { Albumin }(\mathrm{g} / \mathrm{DL}), \\
\text { mean }( \pm \mathrm{SD})\end{array}$ & $\begin{array}{c}\text { Hematocrit }(\%), \\
\text { mean }( \pm \mathrm{SD})\end{array}$ & $\begin{array}{c}\mathrm{ESR}(\mathrm{mm} / \mathrm{h}), \\
\text { mean }( \pm \mathrm{SD})\end{array}$ \\
\hline $\begin{array}{c}\text { Healthy controls } \\
N=10^{*}\end{array}$ & $4.2(0.9)$ & $39.6(3.7)$ & $23.7(15.3)$ \\
$\mathrm{CD}$ patients & & & \\
$\mathrm{N}=21$ & $3.5(0.5)$ & $34.5(3.4)$ & $29.7(25.4)$ \\
$p$ value & 0.016 & 0.0007 & 0.56 \\
\hline
\end{tabular}

* Not all subjects had clinical data available.

Table 3. Levels of albumin, hematocrit and ESR by gender, BMI, race, and ethnicity in $C D$ patients and controls

\begin{tabular}{lccc}
\hline & $\begin{array}{c}\text { Albumin }(\mathrm{g} / \mathrm{DL}), \\
\text { mean }( \pm \mathrm{SD})\end{array}$ & $\begin{array}{c}\text { Hematocrit }(\%), \\
\text { mean }( \pm \mathrm{SD})\end{array}$ & $\begin{array}{c}\text { ESR }(\mathrm{mm} / \mathrm{h}), \\
\text { mean }( \pm \mathrm{SD})\end{array}$ \\
\hline Gender & & & \\
Male & $3.7(0.7)$ & $37.2(4.3)$ & $28.7(24.8)$ \\
Female & $3.7(0.8)$ & $34.5(3.6)$ & $27.3(21.4)$ \\
$p$ value & 0.88 & 0.08 & 0.88 \\
BMI & & & \\
12-18.5 & $3.7(0.8)$ & $35.0(3.7)$ & $30.0(25.7)$ \\
$18.5-25$ & $3.7(0.7)$ & $38.2(4.5)$ & $21.3(20.6)$ \\
$25-42.3$ & $3.8(0.8)$ & $35.2(3.8)$ & $34.2(20.2)$ \\
$p$ value & 0.96 & 0.13 & 0.58 \\
Race & & & \\
Black/AA & $3.4(0.4)$ & $33.7(3.1)$ & $47.3(36.0)$ \\
White & $3.8(0.8)$ & $36.5(4.3)$ & $23.5(19.6)$ \\
$p$ value & 0.39 & 0.09 & 0.18 \\
Ethnicity & & & \\
Hispanic & $3.8(1.0)$ & $38.3(6.5)$ & $21.7(19.4)$ \\
Non-Hispanic & $3.7(0.7)$ & $35.8(3.8)$ & $29.0(23.6)$ \\
$p$ value & 0.80 & 0.28 & 0.61 \\
\hline
\end{tabular}

$6.8-10.2 \%, p=0.006)$ than controls Th1 $(11.7 \% ; 95 \% \mathrm{CI}$, $10.2-13.4 \%)$. However, no significant difference between the two groups was found in the mean percentage of $\mathrm{CD}^{+}{ }^{+} \mathrm{CD}$ patients: $28.6 \%$; $95 \%$ CI, $25.1-32.1 \%$, controls: $30.1 \%$; $95 \%$ CI, 28.2-31.9\%; $p=0.32$ ) or in the Th2 cytokine levels (CD patients: $0.6 \%$; $95 \% \mathrm{CI}, 0.4-0.9 \%$, controls: $0.6 \%$; $95 \% \mathrm{CI}$, $0.4-0.8 \% ; p=0.85)$. As a result, the Th1/Th2 ratio in patients was more skewed toward Th2 in CD patients (17) than in controls (19.5).

Correlation between age and $\mathrm{CD}^{+}, \mathrm{Th1}$, and Th2 in CD patients and controls. Regression lines were generated for 
Table 4. Correlations between clinical end points, cytokine levels, and age

\begin{tabular}{|c|c|c|c|c|c|c|}
\hline & \multicolumn{2}{|c|}{ Albumin } & \multicolumn{2}{|c|}{ Hematocrit } & \multicolumn{2}{|c|}{ ESR } \\
\hline & $r^{*}$ & $p$ value & $r$ & $p$ value & $r$ & $p$ value \\
\hline CD4 & 0.100 & 0.619 & 0.005 & 0.980 & -0.089 & 0.665 \\
\hline Th1† & 0.509 & 0.007 & 0.352 & 0.052 & -0.227 & 0.266 \\
\hline $\operatorname{Th} 2 \dagger$ & -0.012 & 0.953 & 0.307 & 0.094 & 0.002 & 0.992 \\
\hline Age & -0.083 & 0.679 & 0.124 & 0.508 & 0.250 & 0.218 \\
\hline
\end{tabular}

* Correlation coefficients.

$\dagger$ Log-transformed to obtain normal distribution of percent cytokines.

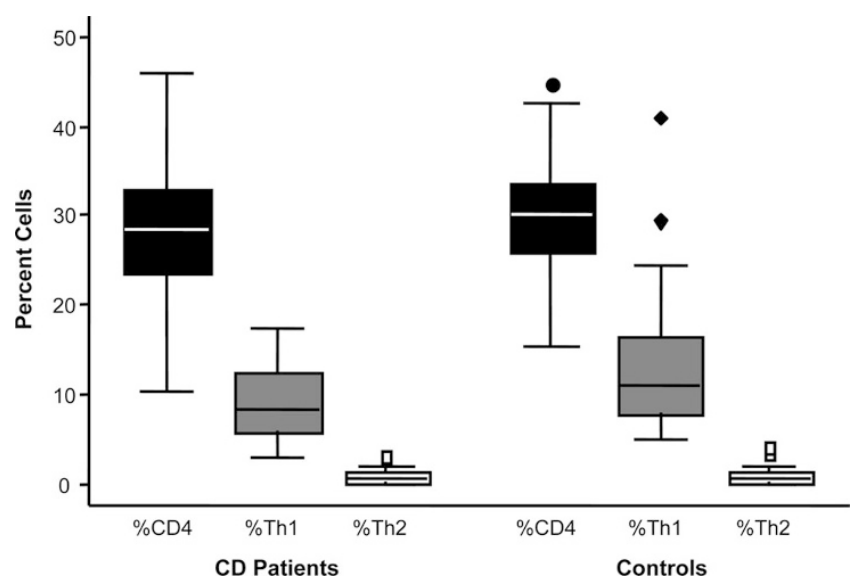

Figure 2. Percentage of $\mathrm{CD} 4{ }^{+}$, Th1, and Th2 cells among $\mathrm{CD}$ patients and controls. Comparison of CD4\%, Th1\%, and Th2\% between CD patients and controls. Th1\% is significantly lower in CD patients than in healthy children ( $p=0.006)$. CD $4 \%$ and Th2\% showed no significant difference between CD patients and controls.

$\mathrm{CD} 4^{+}$, Th1, and Th2 cell percentage by age and were plotted in Fig. $3 A-C$. Results of the regression are summarized in Table 5. After controlling for patient status, a 1-y increase in age was associated with a $6 \%$ increase in Th1 cells [95\% CI $(3 \%, 0 \%) p<0.0005]$. Additionally, after controlling for age, CD patients had on average $33 \%$ lower number of Th1 cells than healthy controls $[95 \% \mathrm{CI}(-55 \%,-12 \%) p=0.003]$. No association was observed between age and $\mathrm{CD} 4^{+}$or Th2 cells in either $\mathrm{CD}$ patients or controls $\left(\mathrm{CD}^{+}{ }^{+}\right.$in controls, $p=0.49$; $\mathrm{CD} 4{ }^{+}$in patients, $p=0.81$; Fig. $3 A$; Th2 in controls, $p=$ 0.18 ; Th2 in patients, $p=0.62$; Fig. $3 C$ ), although the regression line for Th2\% showed a downward trend $(p=$ 0.12) over age in both CD patients and controls (Fig. 3C).

Potential confounders that may affect the intracellular Th1/Th2 cytokine levels. In addition to age, other factors such as gender, race, or BMI may also affect cytokine levels in children. Distributions of $\mathrm{CD}^{+}$, Th1, and Th2 cells by potential confounders are shown in Table 6. No differences between $\mathrm{CD}$ patients and controls were found for levels of $\mathrm{CD} 4^{+}$, Th1, and Th2 cell populations by gender or race. Although an increasing trend for percentage of Th1 cells in CD patients was observed with higher BMI levels, the difference among the three BMI categories was borderline significant $(p=0.06)$ only. Therefore, no adjustments for these factors were made when studying the association between cytokine levels and age. No differences were observed for either CD patients or controls when ANOVA analysis was
Table 5. Regression results for effects of age and patient status on Th1, Th2, and CD4 levels

\begin{tabular}{|c|c|c|}
\hline & $\begin{array}{l}\text { Beta coefficient } \\
\quad(95 \% \mathrm{CI})\end{array}$ & $p$ value \\
\hline \multicolumn{3}{|l|}{$\mathrm{CD} 4$} \\
\hline Age & $0.12(-0.39,0.63)$ & 0.641 \\
\hline CD patients & $-1.44(-5.01,2.12)$ & 0.422 \\
\hline Healthy controls* & - & - \\
\hline \multicolumn{3}{|l|}{ Th1† } \\
\hline Age & $0.06(0.03,0.09)$ & $<0.0005$ \\
\hline $\mathrm{CD}$ patients & $-0.33(-0.55,-0.12)$ & 0.003 \\
\hline Healthy controls* & - & - \\
\hline \multicolumn{3}{|l|}{$\operatorname{Th} 2 \dagger$} \\
\hline Age & $-0.06(-0.13,0.02)$ & 0.123 \\
\hline $\mathrm{CD}$ patients & $0.01(-0.51,0.53)$ & 0.975 \\
\hline Healthy controls* & - & - \\
\hline
\end{tabular}

performed to compare the status of $\mathrm{CD} 4^{+}$, Th1, and Th2 cell populations at different collection months (data not shown).

\section{DISCUSSION}

Our data for $\mathrm{CD}^{+}{ }^{+}$, Th1, and Th2 cell frequency analyzed in peripheral blood by flow cytometry, reveals lower numbers of Th1 cells in the peripheral blood of treatment-naïve children with $\mathrm{CD}$ compared with matched healthy controls. In contrast, the levels of $\mathrm{CD}^{+}$and $\mathrm{Th} 2$ cells did not differ between $\mathrm{CD}$ patients and controls. A number of studies have examined the expression of $\mathrm{T}$ cell cytokines in intestinal mucosa and found increased levels of IFN- $\gamma$ mRNA and frequencies of IFN- $\gamma$ producing T-cells in adult patients with IBD compared with controls $(7,8,33)$. However, the only available study of young children with newly diagnosed untreated IBD, which used flow cytometric assay of blood lymphocytes as in our study, also found the median Th1\% in CD patients $(n=14)$ was lower than in healthy subjects $(n=$ 9). Thus, the results in newly diagnosed pediatric CD patients are discordant with other studies of cytokine changes associated with IBD. Several factors, including age of patients at diagnosis, stage of disease progression, prior medication or environmental exposures (especially over time in older patients), tissue type, and methods of cytokine analysis, can potentially contribute to the difference in results. First, most previous studies involved older patients with long-standing disease or patients undergoing various therapeutic interventions; therefore, the patterns of cytokine expression could be influenced by these factors. Second, as serum cytokine bioassays detect the cytokines from both lymphocytes and macrophages; the source of elevated Th1 cytokines cannot be specified $(7,8)$. Using flow cytometric analysis of intracellular cytokines, Van Damme et al. have examined different subtypes of colonic lamina propia lymphocytes from IBD patients and found no difference in the frequencies of IFN- $\gamma$ producing $\mathrm{CD}^{+} \mathrm{CD}^{+}$cells between controls and patients (18). In contrast, significant lower percentages of IFN- $\gamma$ producing $\mathrm{CD}^{+} \mathrm{CD}^{-}$cells were observed in patients compared with controls. Third, the circulating and intestinal cytokine levels may be different and further affected by the progression of 

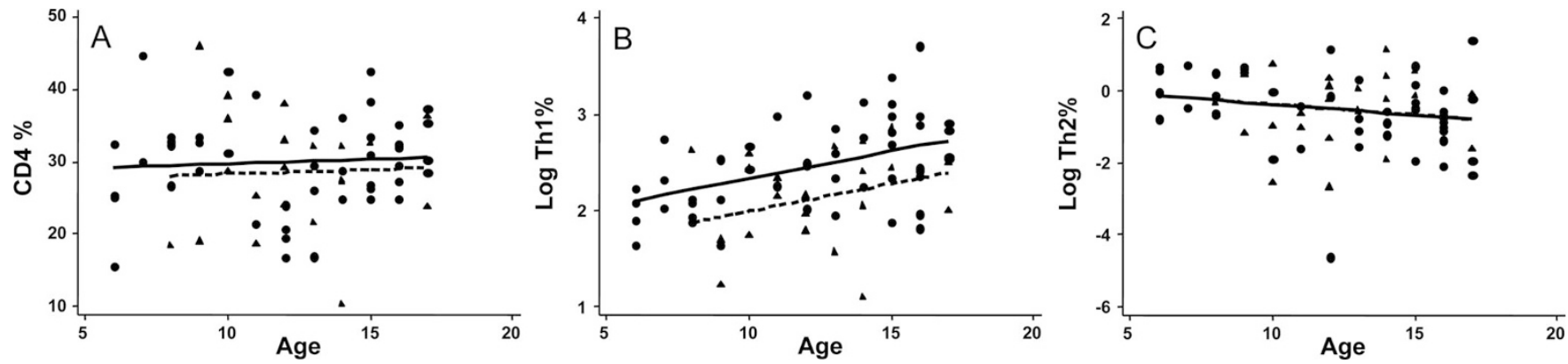

Figure 3. Association of $\mathrm{CD}^{+}(A)$, Th1 $(B)$, and Th2 $(C)$ cell percentage with age for $\mathrm{CD}$ patients and controls. The relationship between age and percent of $\mathrm{CD}^{+}(A)$, Th1 $(B)$, and Th2 $(C)$ cells in CD patients ( $\mathbf{\Delta}$; dashed lines) and healthy controls $(\mathbf{O}$; solid lines). Th1\% was significantly associated with age (y) in controls and CD patients $(p<0.0005)$ after adjusting for patient status in multiple linear regression analysis. The regression lines for Th2 in CD patients and controls overlap indicating no statistically significant differences between the two groups. No statistically significant association was observed between age and CD4 or Th2.

Table 6. Percent of CD4, Th1, and Th2 by gender, race, ethnicity, and BMI

\begin{tabular}{|c|c|c|c|c|c|c|}
\hline & \multicolumn{2}{|c|}{$\begin{array}{l}\% \mathrm{CD} 4, \text { mean } \\
\quad( \pm \mathrm{SD})\end{array}$} & \multicolumn{2}{|c|}{$\begin{array}{c}\% \text { Th } 1 * \text {, geometric mean } \\
( \pm \mathrm{SD})\end{array}$} & \multicolumn{2}{|c|}{$\begin{array}{c}\% \mathrm{Th} 2 * \text {, geometric mean } \\
( \pm \mathrm{SD})\end{array}$} \\
\hline & Control & Patients & Control & Patients & Control & Patients \\
\hline \multicolumn{7}{|l|}{ Gender } \\
\hline Male & $28.7(7.1)$ & $28.7(5.8)$ & $10.5(1.6)$ & $8.3(1.6)$ & $0.7(3.3)$ & $0.7(2.4)$ \\
\hline Female & $31.7(5.4)$ & $28.5(11.2)$ & $13.4(1.6)$ & $8.4(1.8)$ & $0.5(2.4)$ & $0.5(3.6)$ \\
\hline$p$ value & 0.14 & 0.90 & 0.09 & 0.83 & 0.21 & 0.53 \\
\hline \multicolumn{7}{|l|}{ Race } \\
\hline Black/AA & $29.6(4.6)$ & $24.1(8.4)$ & $14.9(1.4)$ & $9.5(1.7)$ & $0.6(1.8)$ & $0.6(1.2)$ \\
\hline White & $29.6(6.6)$ & $28.4(7.4)$ & $11.5(1.6)$ & $8.6(1.6)$ & $0.6(3.2)$ & $0.6(1.6)$ \\
\hline Others $\dagger$ & $34.7(6.1)$ & 46.1 & $11.2(1.7)$ & 3.4 & $0.8(1.6)$ & 0.3 \\
\hline$p$ value & 0.28 & 0.07 & 0.44 & 0.12 & 0.85 & 0.80 \\
\hline \multicolumn{7}{|l|}{ Ethnicity } \\
\hline Hispanic & $30.9(8.6)$ & $31.5(10.8)$ & $13.9(1.9)$ & $8.4(1.8)$ & $0.7(1.8)$ & $0.3(5.8)$ \\
\hline Non-Hispanic & $29.9(6.1)$ & $28.3(8.1)$ & $11.3(1.6)$ & $8.4(1.7)$ & $0.6(3.2)$ & $0.6(2.6)$ \\
\hline$p$ value & 0.65 & 0.57 & 0.31 & 0.91 & 0.58 & 0.30 \\
\hline \multicolumn{7}{|l|}{ BMI } \\
\hline $12-18.5$ & $30.0(6.9)$ & $30.2(8.9)$ & $10.2(1.4)$ & $7.4(1.8)$ & $0.7(4.2)$ & $0.6(3.0)$ \\
\hline $18.5-25$ & $29.2(6.9)$ & $27.3(7.4)$ & $12.5(1.7)$ & $8.9(1.6)$ & $0.6(2.5)$ & $0.7(2.3)$ \\
\hline $25-42.3$ & $31.1(5.7)$ & $26.2(7.5)$ & $12.2(1.6)$ & $10.9(1.4)$ & $0.5(2.5)$ & $0.6(2.1)$ \\
\hline$p$ value & 0.44 & 0.71 & 0.74 & 0.06 & 0.12 & 0.77 \\
\hline
\end{tabular}

* Log-transformed to obtain normal distribution of percent cytokines.

$\dagger$ Category "Others" includes 1 2 individuals of each group who self-identified as Asian, Native American, White, and Native American Mixed race, White and Pacific Islander Mixed race, or refused to define their race.

IBD disease, although a correlation between lamina propia $\mathrm{CD} 4{ }^{+} \mathrm{T}$-cells and peripheral blood $\mathrm{CD} 4^{+} \mathrm{T}$ cells was previously reported (34). Further, it is possible that cytokine profiles could be different at new-onset and remission cases (19).

The association between age and cytokine levels has been studied in infancy and early childhood (24-27); however, none of the studies looked at the ontogeny of cytokine levels in IBD patients. In the present research, we showed that CD4 ${ }^{+}$ cell frequency remained constant in controls and patients over age, whereas the percentage of Th1 cells increased linearly with age in both healthy controls and patients. This data corroborates reported associations between age and Th1 cell frequencies (24-26) or Th1 protein levels (27) in healthy children. In addition, after adjusting for age, Th1 cell frequency was significantly lower in patients compared with controls. The multiple regression analysis of Th2 data in both CD patients and controls revealed a slight downward trend over age, although it was not statistically significant.
One limitation of this study is its relatively small sample size, as illustrated by the $p=0.1$ for the group comparison of BMI, despite a noticeable difference between CD patients and controls. However, this is the largest dataset available for newly diagnosed pediatric CD patients and matched controls. Additionally, we should remain cautious when interpreting the physiologic implications of the Th1/Th2 imbalance in CD patients because the in vitro expression of cytokines after PMA and ionomycin stimulation may not directly reflect the in vivo changes of these cytokines during disease progression in intestinal mucosa and peripheral blood. Nevertheless, predictive value of Th1 cytokine levels in newly diagnosed CD patients is enhanced by statistically significant correlations with diseaserelated clinical results such as lower albumin and hematocrit.

Our study shows a decrease in IFN- $\gamma$ producing $\mathrm{CD}^{+}$cells in peripheral blood of the treatment-naive pediatric $\mathrm{CD}$ patients compared with controls. We observed increases in percentage of IFN- $\gamma$ positive $\mathrm{CD} 4^{+}$with age in both healthy 
children and CD patients. In future studies, it will be interesting to explore the pattern of other cytokines including IL-17, which is upregulated in adults with active IBD (35-38), and to compare intracellular cytokines with mRNA expression and secreted proteins in intestinal mucosa and peripheral blood of newly diagnosed and treated pediatric IBD patients.

\section{REFERENCES}

1. Hait E, Bousvaros A, Grand R 2005 Pediatric inflammatory bowel disease: what children can teach adults. Inflamm Bowel Dis 11:519-527

2. Fiocchi C 1998 Inflammatory bowel disease: etiology and pathogenesis. Gastroenterology 115:182-205

3. Podolsky DK 2002 Inflammatory bowel disease. N Engl J Med 347:417-429

4. Monteleone G, Monteleone I, Fina D, Vavassori P, Del Vecchio Blanco G, Caruso R, Tersigni R, Alessandroni L, Biancone L, Naccari GC, MacDonald TT, Pallone F 2005 Interleukin-21 enhances T-helper cell type I signaling and interferon-gamma production in Crohn's disease. Gastroenterology 128:687-694

5. Peluso I, Pallone F, Monteleone G 2006 Interleukin-12 and Th1 immune response in Crohn's disease: pathogenetic relevance and therapeutic implication. World J Gastroenterol 12:5606-5610

6. Rogler G, Andus T 1998 Cytokines in inflammatory bowel disease. World J Surg 22:382-389

7. Fais S, Capobianchi MR, Pallone F, Di Marco P, Boirivant M, Dianzani F, Torsoli A 1991 Spontaneous release of interferon gamma by intestinal lamina propria lymphocytes in Crohn's disease. Kinetics of in vitro response to interferon gamma inducers. Gut 32:403-407

8. Breese E, Braegger CP, Corrigan CJ, Walker-Smith JA, MacDonald TT 1993 Interleukin-2- and interferon-gamma-secreting T cells in normal and diseased human intestinal mucosa. Immunology 78:127-131

9. Garg AK, Aggarwal BB 2002 Reactive oxygen intermediates in TNF signaling. Mol Immunol 39:509-517

10. Brandonisio O, Panaro MA, Sisto M, Acquafredda A, Fumarola L, Leogrande D, Mitolo V 2001 Nitric oxide production by Leishmania-infected macrophages and modulation by cytokines and prostaglandins. Parassitologia 43:1-6

11. Nassif A, Longo WE, Mazuski JE, Vernava AM, Kaminski DL 1996 Role of cytokines and platelet-activating factor in inflammatory bowel disease. Implications for therapy. Dis Colon Rectum 39:217-223

12. Mosmann TR, Coffman RL 1989 TH1 and TH2 cells: different patterns of lymphokine secretion lead to different functional properties. Annu Rev Immunol 7:145-173

13. Duramad P, Tager IB, Holland NT 2007 Cytokines and other immunological biomarkers in children's environmental health studies. Toxicol Lett 172:48-59

14. Moser M, Murphy KM 2000 Dendritic cell regulation of TH1-TH2 development. Nat Immunol 1:199-205

15. Romagnani S 1994 Lymphokine production by human T cells in disease states. Annu Rev Immunol 12:227-257

16. Oriss TB, McCarthy SA, Morel BF, Campana MA, Morel PA 1997 Crossregulation between T helper cell (Th)1 and Th2: inhibition of Th2 proliferation by IFN-gamma involves interference with IL-1. J Immunol 158:3666-3672

17. Radford-Smith G, Jewell DP 1996 Cytokines and inflammatory bowel disease. Baillieres Clin Gastroenterol 10:151-164

18. Van Damme N, De Keyser F, Demetter P, Baeten D, Mielants H, Verbruggen G, Cuvelier C, Veys EM, De Vos M 2001 The proportion of Th1 cells, which prevail in gut mucosa, is decreased in inflammatory bowel syndrome. Clin Exp Immunol 125:383-390
19. Mack DR, Beedle S, Warren J, Davis J, Gross T 2002 Peripheral blood intracellular cytokine analysis in children newly diagnosed with inflammatory bowel disease. Pediatr Res 51:328-332

20. Desreumaux P, Brandt E, Gambiez L, Emilie D, Geboes K, Klein O, Ectors N, Cortot A, Capron M, Colombel JF 1997 Distinct cytokine patterns in early and chronic ileal lesions of Crohn's disease. Gastroenterology 113:118-126

21. Fuss IJ, Neurath M, Boirivant M, Klein JS, de la Motte C, Strong SA, Fiocchi C, Strober W 1996 Disparate CD4+ lamina propria (LP) lymphokine secretion profiles in inflammatory bowel disease. Crohn's disease LP cells manifest increased secretion of IFN-gamma, whereas ulcerative colitis LP cells manifest increased secretion of IL-5. J Immunol 157:1261-1270

22. West GA, Matsuura T, Levine AD, Klein JS, Fiocchi C 1996 Interleukin 4 in inflammatory bowel disease and mucosal immune reactivity. Gastroenterology 110:1683-1695

23. Karttunnen R, Breese EJ, Walker-Smith JA, MacDonald TT 1994 Decreased mucosal interleukin-4 (IL-4) production in gut inflammation. J Clin Pathol 47:10151018

24. Kawamoto N, Kaneko H, Takemura M, Seishima M, Sakurai S, Fukao T, Kasahara $\mathrm{K}$, Iwasa S, Kondo N 2006 Age-related changes in intracellular cytokine profiles and Th2 dominance in allergic children. Pediatr Allergy Immunol 17:125-133

25. Hartel C, Adam N, Strunk T, Temming P, Muller-Steinhardt M, Schultz C 2005 Cytokine responses correlate differentially with age in infancy and early childhood. Clin Exp Immunol 142:446-453

26. Chipeta J, Komada Y, Zhang XL, Deguchi T, Sugiyama K, Azuma E, Sakurai M 1998 CD4+ and CD8 + cell cytokine profiles in neonates, older children, and adults: increasing $\mathrm{T}$ helper type 1 and $\mathrm{T}$ cytotoxic type 1 cell populations with age. Cell Immunol 183:149-156

27. Smart JM, Kemp AS 2001 Ontogeny of T-helper 1 and T-helper 2 cytokine production in childhood. Pediatr Allergy Immunol 12:181-187

28. Duramad P, McMahon CW, Hubbard A, Eskenazi B, Holland NT 2004 Flow cytometric detection of intracellular TH1/TH2 cytokines using whole blood: validation of immunologic biomarker for use in epidemiologic studies. Cancer Epidemiol Biomarkers Prev 13:1452-1458

29. McNerlan SE, Alexander HD, Rea IM 1999 Age-related reference intervals for lymphocyte subsets in whole blood of healthy individuals. Scand J Clin Lab Invest 59:89-92

30. Heyman MB, Kirschner BS, Gold BD, Ferry G, Baldassano R, Cohen SA, Winter HS, Fain P, King C, Smith T, El-Serag HB 2005 Children with early-onset inflammatory bowel disease (IBD): analysis of a pediatric IBD consortium registry. J Pediatr 146:35-40

31. Hyams JS 2005 Inflammatory bowel disease. Pediatr Rev 26:314-320

32. Younge L, Norton C 2007 Contribution of specialist nurses in managing patients with IBD. Br J Nurs 16:208-212

33. Bamias G, Martin C III, Marini M, Hoang S, Mishina M, Ross WG, Sachedina MA, Friel CM, Mize J, Bickston SJ, Pizarro TT, Wei P, Cominelli F 2003 Expression, localization, and functional activity of TL1A, a novel Th1-polarizing cytokine in inflammatory bowel disease. J Immunol 171:4868-4874

34. Fiocchi C, Fukushima K, Strong SA, Ina K 1996 Pitfalls in cytokine analysis in inflammatory bowel disease. Aliment Pharmacol Ther 10:63-69; discussion 70-61

35. Nielsen OH, Kirman I, Rudiger N, Hendel J, Vainer B 2003 Upregulation of interleukin-12 and -17 in active inflammatory bowel disease. Scand J Gastroenterol 38:180-185

36. Fujino S, Andoh A, Bamba S, Ogawa A, Hata K, Araki Y, Bamba T, Fujiyama Y 2003 Increased expression of interleukin 17 in inflammatory bowel disease. Gut 52:65-70

37. Mudter J, Neurath MF 2007 Il-6 signaling in inflammatory bowel disease: pathophysiological role and clinical relevance. Inflamm Bowel Dis 13:1016-1023

38. Yen D, Cheung J, Scheerens H, Poulet F, McClanahan T, McKenzie B, Kleinschek MA, Owyang A, Mattson J, Blumenschein W, Murphy E, Sathe M, Cua DJ, Kastelein RA, Rennick D 2006 IL-23 is essential for T cell-mediated colitis and promotes inflammation via IL-17 and IL-6. J Clin Invest 116:1310-1316 